\title{
Effect of Lacticaseibacillus rhamnosus Yoba Fermentation on Physicochemical Properties, Amino Acids, and Antioxidant Activity of Cowpea-Peanut Milk
}

\author{
Armistice Chawafambira $\mathbb{D}^{1},{ }^{1}$ Talknice Zvamaziva Jombo $(\mathbb{D})^{2}$ \\ and Tafadzwa Mkungunugwa ${ }^{3}$ \\ ${ }^{1}$ Department of Food Science and Technology, Chinhoyi University of Technology, P. Bag 7724, Chinhoyi, \\ Mashonaland West, Zimbabwe \\ ${ }^{2}$ Department of Food Science and Nutrition, Midlands State University, P. Bag 9055, Gweru, Zimbabwe \\ ${ }^{3}$ Chemical and Food Technology Division, Standards Association of Zimbabwe, 17 Coventry Rd, Workington, Harare, Zimbabwe
}

Correspondence should be addressed to Armistice Chawafambira; achawazie@gmail.com

Received 28 August 2021; Revised 18 January 2022; Accepted 9 February 2022; Published 28 February 2022

Academic Editor: Maria Rosaria Corbo

Copyright (C) 2022 Armistice Chawafambira et al. This is an open access article distributed under the Creative Commons Attribution License, which permits unrestricted use, distribution, and reproduction in any medium, provided the original work is properly cited.

\begin{abstract}
The global renewed interest in plant-based milk and products is increasing amongst health-conscious consumers. There is increased utilisation of generic probiotics in the processing of legume milk as alternatives to dairy milk are scarce in Africa. This study evaluated the probiotic potential, physicochemical, and sensory properties of novel fermented cowpea-peanut milk with Lacticaseibacillus rhamnosus Yoba. A $3 \times 1$ factorial design as ratio of cowpea-peanut milk $(1: 1,2: 1,3: 1 \mathrm{v} / \mathrm{v})$ and the application of $2 \% \mathrm{w} / \mathrm{v} L$. rhamnosus Yoba obtained from Yoba for Life Foundation, Netherlands, was used. The chemical and mineral contents of the fermented cowpeapeanut milk was analysed using Association of Official Analytical Chemists (AOAC) methods. Quality parameters such as 2,2diphenyl-1-picrylhydrazyl (DPPH) free radical scavenging rate, total antioxidant activity, antinutrient, and amino acids content were determined. The fermented cowpea-peanut milk samples had 7.7-8.1 log CFU/mL viable L. rhamnosus Yoba cells after fermentation. Nutrient content range was given in g/100 g: carbohydrate 5.18-6.05, crude fat 3.3-3.5, crude protein 5.6-7.1, ash 1.04-1.26, crude fibre $0.72-1.18$, and total reducing sugars 1.80-2.20. Lysine, leucine, and methionine content was $6.30-7.31,6.60-8.75$, and $1.7-1.86 \mathrm{~g} / 100 \mathrm{~g}$, respectively. Phytic acid and trypsin inhibitor content range was $0.3-0.34 \mathrm{mg} / 100 \mathrm{~g}$ and $0.86-1.12 \mathrm{TIU} / \mathrm{mg}$, respectively. Iron and potassium content $(\mathrm{mg} / 100 \mathrm{~g})$ was $0.48-0.58$ and $202-243$ with $\mathrm{pH} 4.1-4.2$. DPPH free radical scavenging, and total antioxidant rate was $56-59 \%$ and $49-54 \%$, respectively. Physicochemical parameters were significantly different $(p<0.05)$. The fermented cowpeapeanut milk had an acceptance rating of $78 \%$. The successful application and consumer acceptability of the fermented cowpea-peanut milk has the potential to increase the utilisation of these legumes and enhance their market value.
\end{abstract}

\section{Introduction}

Of late, the utilisation of alternative protein sources in food processing is on an increase due to the global concerns on food security, protein malnutrition, and population growth. The great shift towards the consumption of plant-based foods which consist of legumes, nuts, seeds, cereals, fruits, and vegetables is being promoted [1]. Plant-based milk is becoming an important food in the vegetarian food industry [2]. They play an important role in the diets of consumers who are allergic to cow's milk or have lactose intolerance. Plant-based milk is an extracted fluid in water obtained from the process of maceration, grinding, and filtration [3].

COVID-19 is likely to have a major impact on global food and nutrition security, especially in Southern Africa [4]. To further promote the application of plant-based milk in the food industry, it is important to understand their potential to support the growth of probiotic bacteria which influence their technofunctional properties such as foaming, solubility, gelation, and emulsification capacity in food 
matrices. Probiotics are defined as live microorganisms which when administered in adequate amounts confer a health benefit on the host [5]. A generic probiotic, Lactobacillus rhamnosus Yoba, 2012, is being promoted and applied as a practical solution for accessing probiotic foods, especially to many rural folks in Africa [6]. Studies on the probiotics have found the ability of the bacteria to grow and ferment fruit pulp substrate [7]. A recent study on "a taxonomic note on the genus Lactobacillus: Description of 23 novel genera, emended description of the genus Lactobacillus Beijerinck 1901, and union of Lactobacillaceae and Leuconostocaceae" resulted in the reclassification of L. rhamnosus to Lacticaseibacillus rhamnosus [8].

Previously, legumes have been used in the production of many plant-based milk products such as chocolate milk drinks [9] and powdered milk [10]. The functional properties of legumes and oilseeds make it suitable to combine them and produce acceptable food products. In the case of cowpea milk, it has low energy; whereas, peanut milk is high in energy [11]. The blending of the two products effectively reduces the limitations they have individually [12]. Apart from rich nutrients, cowpeas are good sources of dietary fibre, polyphenols, polyunsaturated fatty acids (PUFA), and antioxidants [13]. Studies on the health benefits of plantbased milk include the reduction of the risk of cardiovascular diseases, atherosclerosis, diabetes, and cancer [14]. The use of lactic acid bacteria (LAB) in the fermentation of plantbased milk is a subtrend of innovative plant-based products that improve their technofunctional properties, nutrition, safety, and shelf life [15]. Studies have been carried out on the functional properties of plant-based fermented milk $[15,16]$. Soybean milk fermented with Lactobacillus paracase $i$ had a good antioxidative capacity and vitamin B groups [17].

Plant-based milk has problems of low acceptability due to unpleasant taste and smell and low bioaccessibility of minerals due to the presence of antinutritive compounds. Information on the utilisation of cowpea-peanut milk in fermented food is scarce. Conversely, whether the physicochemical and technofunctional properties of cowpeapeanut milk can be positively influenced by fermentation using probiotics that remain unknown. Therefore, this study aimed to evaluate the probiotic potential, physicochemical, amino acid content, antioxidant activity, and sensorial quality of cowpea-peanut milk fermented with Lacticaseibacillus rhamnosus Yoba. This information has the potential to increase the application of Lacticaseibacillus rhamnosus Yoba in new food product development and promote the use of cowpea-peanut milk as an ingredient in the formulation of many food products.

\section{Materials and Methods}

2.1. Raw Materials. The most common cowpea variety (Vigna unguiculata), locally called "nyemba in Shona" and peanuts (Arachis hypogaea), was purchased on a local market in Chinhoyi, Zimbabwe. The legume grains were sorted and cleaned by removing rotten grains as well as any extraneous materials from the lot.
2.1.1. Research Design. A $3 \times 1$ factorial design was followed: (a) the ratio of cowpea-peanut $(1: 1,2: 1,3: 1)$ and (b) the application of Lacticaseibacillus rhamnosus Yoba. The production of legume milk is illustrated using a flowchart, as shown in Figure 1.

2.1.2. Sample Pretreatments. The pretreatments were conducted according to a method described by Asiamah [12], with slight modifications. The weighed $(1 \mathrm{~kg})$ cowpeas samples were steeped in distilled water for $5 \mathrm{~min}$ and dehulled. The dehulled cowpeas were then steeped in $0.75 \%$ w/v baking soda (sodium hydrogen carbonate) $\left(\mathrm{NaHCO}_{3}\right)$ at $\mathrm{pH} 8$, for 6 hours (h), and then washed in distilled water. Similarly, weighed peanuts were blanched in hot water $\left(80^{\circ} \mathrm{C}\right)$ for $1 \mathrm{~min}$ and then dehulled. The peanuts were further steeped in $1 \% \mathrm{w} / \mathrm{v} \mathrm{NaHCO} 3$ at $\mathrm{pH} 8.2$, for $9 \mathrm{~h}$, and then, the dehulled peanuts were washed in distilled water.

2.1.3. Preparation of Legume Milk. The dehulled cowpeas and peanuts were combined using $1: 1 \mathrm{w} / \mathrm{w}, 2: 1 \mathrm{w} / \mathrm{w}$, and 3 : $1 \mathrm{w} / \mathrm{w}$ ratios according to the experimental design. The mixed grain samples (cowpeas + peanuts) were then mixed with water in a ratio $(1: 2 \mathrm{w} / \mathrm{v})$ and further slurried in a blender. The slurry was then filtered using a double-cheese cloth to obtain milk. Milk was pasteurized at $85^{\circ} \mathrm{C}$ for $5 \mathrm{~min}$ and then allowed to cool to $30^{\circ} \mathrm{C}$. The milk was divided into $1 \mathrm{~L}$ portions. Raw cow's milk, an animal-based product, was used as a control.

2.2. Source of Lacticaseibacillus rhamnosus Yoba. The Lacticaseibacillus rhamnosus Yoba culture was purchased from Yoba for Life Foundation, Netherlands. The generic probiotic, Lacticaseibacillus rhamnosus Yoba, was isolated from a commercial product containing Lacticaseibacillus rhamnosus GG bacteria and identified and confirmed using 16S rRNA sequencing. The purchased Lacticaseibacillus rhamnosus Yoba strain was stored at room temperature $\left(20-25^{\circ} \mathrm{C}\right)$ according to manufacturer' guidelines.

2.2.1. Preparation of Inoculum. Pure strains of Lacticaseibacillus rhamnosus Yoba were reactivated by subculturing anaerobically in De Man, Rogosa, and Sharpe agar (MRS) broth at $37^{\circ} \mathrm{C}$ for $18 \mathrm{~h}$. A preculture medium of cowpeapeanut milk was boiled and then cooled to room temperature $\left(25^{\circ} \mathrm{C}\right)$. Two grams of each reactivated culture were then precultured in the medium and incubated at $37^{\circ} \mathrm{C}$ for 36 hours. The growth of the bacterium was then monitored until the total viable count was $>6 \log \mathrm{CFU} / \mathrm{mL}$.

2.2.2. Inoculation of Probiotic Culture. Sterilized polyethylene terephthalate bottles $(1 \mathrm{~L})$ containing cowpea-peanut milk were opened under aseptic conditions, and the milk was inoculated with $2 \%(\mathrm{v} / \mathrm{v})$ culture. The culture was gently mixed with the milk samples and incubated at a time of $0 \mathrm{~h}$. In the control experiment, cow's milk was inoculated. 


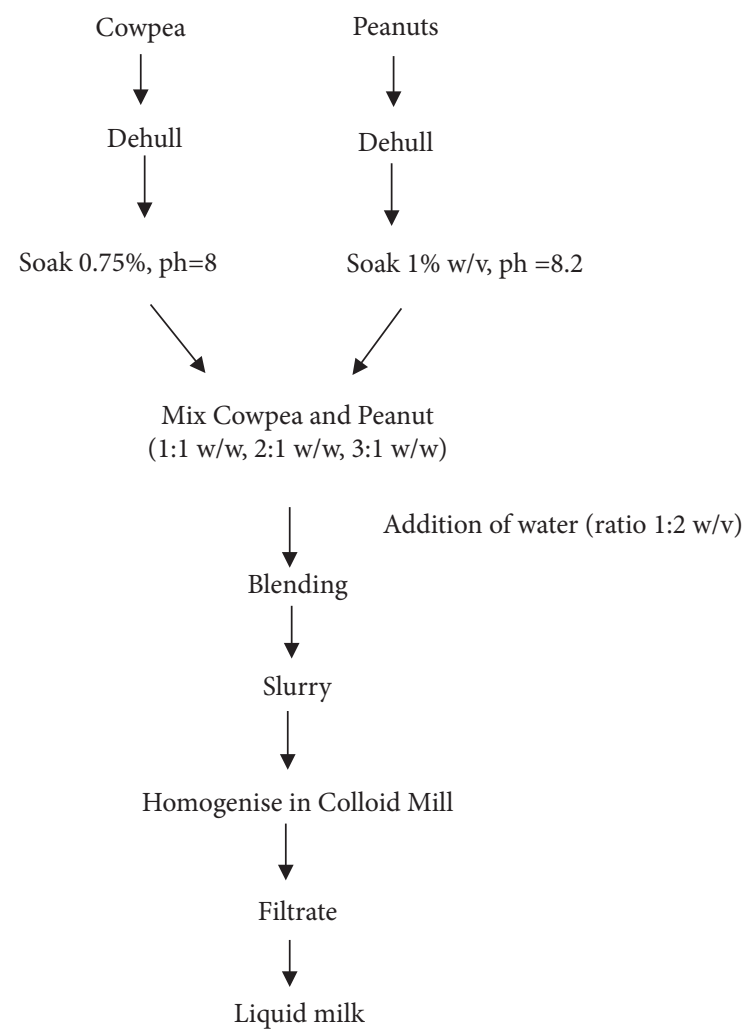

FIGURE 1: Process flowchart of cowpea-peanut milk.

2.3. Determination of Viable Cell Counts. The growth rate of the probiotic bacteria in the cowpea-peanut milk and control milk was monitored for $24 \mathrm{~h}$. Samples were collected every $6 \mathrm{~h}$ over the $24 \mathrm{~h}$ period. One milliliter $(1 \mathrm{~mL})$ of each sample fermented by the probiotic culture was aseptically taken from the sample and suspended in sterile $9 \mathrm{~mL}$ of peptone solution ( $\mathrm{pH} 7,8.5 \mathrm{~g} / \mathrm{L} \mathrm{NaCl}$, and $1 \mathrm{~g} / \mathrm{L}$ neutralized bacteriological peptone from Oxoid). De Man, Rogosa, and MRS agar (1.2\% agar, bacteriological peptone from Oxoid, added to de Man, Rogosa, and Sharpe broth, Merck) was used for culturing Lacticaseibacillus rhamnosus Yoba. Diluents of $100 \mu \mathrm{L}$ from each fermented sample were cultured in triplicates. The cultured MRS agar plates were then incubated under anaerobic conditions at $37^{\circ} \mathrm{C}$ in GasPak anaerobic jars (Becton Dickinson Microbiology Systems, Baltimore, Maryland, USA). The colonies were counted and expressed as colony-forming units per milliliter $(\mathrm{CFU} / \mathrm{mL})$ of each probiotic bacteria.

2.4. Chemical Composition. Proximate analysis on ash content using dry ashing (AOAC method 938.08), moisture content using (AOAC method 925.45), crude fibre using the enzymatic gravimetric method (AOAC method 985.29), and crude protein using Kjeldahl (AOAC method 991.20) were determined according to standard methods described by the AOAC [18]. Total carbohydrate was determined by the difference method.

2.5. $p H$, Titratable Acidity, and Total Sugars. The $\mathrm{pH}$ was determined using a digital $\mathrm{pH}$ meter (BT-675, BOECO, Hamburg, Germany) which was calibrated with $\mathrm{pH} 4.0$ and 7.0 according to the AOAC method [18]. Total soluble solids $\left({ }^{\circ}\right.$ Brix) were determined using a digital refractometer (MA871, North Carolina, Milwaukee Instruments, USA) at $20^{\circ} \mathrm{C}$. Titratable acidity (TA) was determined following a standard method by AOAC [18]. Ten milliliters of the sample was titrated against $0.1 \mathrm{M} \mathrm{NaOH}$ solution using phenolphthalein as an indicator. The $\mathrm{pH}$ and TA measurements were taken at $t=0$, $6,12,18$, and $24 \mathrm{~h}$. The phenol-sulfuric acid method was used to determine the reducing sugars (RS) [19].

2.6. Mineral and Antinutrient Analysis. The mineral content was determined according to the method from AOAC [18] using an inductively coupled plasma optical emission spectrometer (ICP-OES) (Agilent 5100, Agilent Technologies, Santa Clara, California, USA), AOAC [18]. The fermented milk samples were digested using concentrated $\mathrm{HNO}_{3}$ and $\mathrm{H}_{2} \mathrm{SO}_{4}$, followed by the addition of ultrapure $\mathrm{H}_{2} \mathrm{O}_{2}$ to complete digestion and then analysed. The trypsin inhibitor content was determined according to a method by Kakade et al. [20] with few modifications using bovine trypsin and $\mathrm{N} \alpha$-benzoyl-DL arginine 4-nitroanilide hydrochloride (BApNA) as the substrate and bovine trypsin as the standard enzyme, and the phytic acid content was determined using the method by McKie and MccleAry [21] that involved acid extraction of phytic acid and then the dephosphorylation with phytase and alkaline phosphatase.

2.7. Amino Acid Analysis. Essential amino acids were analysed using the HCI hydrolysis process described by Chawafambira et al. [22] with slight modifications. The fermented sample was mixed with $6 \mathrm{~N} \mathrm{HCl}$ in a vial and then mixed and treated with argon to remove oxygen. The mixture in the vial was heated at $110^{\circ} \mathrm{C}$ for $18-24 \mathrm{~h}$ and cooled. The hydrolysate was then centrifuged, filtrated, dried, and then reconstituted using borate buffer for derivatization. Borate buffer $(200 \mu \mathrm{L})$ was then pipetted into a $2 \mathrm{~mL}$ glass vial and mixed with pipetted $10 \mu \mathrm{L}$ of diluted sample. The mixture was then mixed with 6-aminoquinolyl$\mathrm{N}$-hydroxysuccinimidyl carbamate chemical and then vortexed. The vortexed mixture was heated at $55^{\circ} \mathrm{C}$ for $10 \mathrm{~min}$ and loaded into an autosampler tray for analysis. The ultraperformance liquid chromatography (UPLC) with a waters photodiode array detector (Waters, Milford, MA, USA) for high-resolution UPLC-UV was used for analysis. The separation process of the sample was performed using an Acquity UPLC BEH C18 $(2.1 \times 150 \mathrm{~mm} ; 1.7 \mu \mathrm{m}$ particle size $)$ column at $60^{\circ} \mathrm{C}$ at a flow rate of $0.4 \mathrm{ml} / \mathrm{min}$. Results were determined at a wavelength of $254 \mathrm{~nm}$, and the amino acid content was expressed as $\mathrm{mg} / 100 \mathrm{~g}$.

2.8. DPPH Free Radical Scavenging and Total Antioxidant Activity Assay. The 2,2-diphenyl-1-picrylhydrazyl free radical scavenging activity of the fermented samples was analysed using the method described by AOAC [18] with slight modifications. Each $1 \mathrm{~mL}$ sample of $0,6,12,18$, and $24 \mathrm{~h}$ was mixed with $3 \mathrm{~mL}$ of $0.2 \mathrm{mmol} / \mathrm{L} \mathrm{DPPH}$ methanolic solution. The absorbance of the reaction mixture was 
measured at $517 \mathrm{~nm}$ using a Spectronic Genesys spectrophotometer (Genesys 5, Thermo Fisher Scientific, Waltham, Massachusetts, USA) after calibration with methanol in darkness at $25^{\circ} \mathrm{C}$ for $30 \mathrm{~min}$. The $\mathrm{DPPH}$ free radical scavenging rate of each sample was determined as the percentage decrease in absorbance with time.

The total antioxidant activity was determined using the ABTS method as described by Yu et al. [23] with modifications. ABTS $+(7 \mathrm{mmol} / \mathrm{L})$ and potassium persulfate $\left(\mathrm{K}_{2} \mathrm{~S}_{2} \mathrm{O}_{8}\right) \quad(140 \mathrm{mmol} / \mathrm{L})$ were prepared, and then, $1.76 \mathrm{~mL} \mathrm{~K}_{2} \mathrm{~S}_{2} \mathrm{O}_{8}$ solution and $100 \mathrm{~mL} \mathrm{ABTS}+$ were mixed and left to react in the dark. The prepared liquid with $95 \%$ ethanol was then diluted, and its absorbance was analysed. $1.0 \mathrm{~mL}$ of each sample was then mixed with $3 \mathrm{~mL}$ of ABTS radical solution, and the decolorisation of the ABTS + radical cation by the sample was recorded in a Spectronic Genesys spectrophotometer (Genesys 5, Thermo Fisher Scientific, Waltham, Massachusetts, USA) at $734 \mathrm{~nm}$.

2.9. Sensory Analysis. A total of 50 untrained panellists consisting of men and women were randomly selected to participate in the sensory evaluation process. Consent forms were obtained from volunteer participants. The fermented cowpea-peanut milk samples were coded using a three-digit code. Vanilla and sugar were added to the samples. Each panelist was given a pen, a sensory evaluation scorecard, and a bottle of water to rinse their mouth after each analysis and were placed in individual testing booths. A 5-point hedonic scale (1, very bad; 2 , bad; 3 , average; 4 , good; 5 , very good) was designed. The panellists were asked to evaluate product attribute: taste, colour, texture, aroma, appearance, and overall acceptance. Panelists were not allowed to discuss their responses during the sensory evaluation process.

2.10. Statistical Analysis. The Kruskal-Wallis nonparametric test will be used to determine any significant differences in the nutritional composition. The least significant difference (LSD) test will be used to compare the means. Multivariate analysis will be performed using analysis of variances (ANOVA) at $p<0.05$ using Sigma Plot for Windows version 12.0.

\section{Results and Discussion}

3.1. Chemical Characteristics of the Fermented Peanut-Cowpea Milk. The fermented cowpea-peanut milk had a crude protein content range of 5.6-6.8\% (Table 1). The addition of peanut milk was beneficial in improving the protein because of the high protein content of peanuts $(25.80 \mathrm{~g} / 100 \mathrm{~g})$ as compared to cowpea $(8-13 \mathrm{~g} / 100 \mathrm{~g})$ [24]. The utilisation of proteins during fermentation might have resulted in the lower content than the generally expected value in the fermented cowpea-peanut milk and the control sample.

The carbohydrate content of the control sample (4.25\%) was lower as compared to the fermented cowpea-peanut milk samples (5.18-6.05\%). The carbohydrate content was high in fermented cowpea-peanut milk sample $(3: 1)$ and significantly different $(p<0.05)$ in other fermented samples $(1: 1,2: 1$ and control) after $24 \mathrm{~h}$ of fermentation. As the ratio of cowpeas increased, the carbohydrate content increased in the fermented cowpea-peanut milk samples. This might be attributed to the high carbohydrate content of cowpea (53-66\%) which is mostly starch and has a good C-type starch crystallinity and high amylose content [25]. This carbohydrate has a low glycemic index (GI), and this makes the fermented cowpea-peanut milk beneficial in preventing diabetes, obesity, and cardiovascular diseases [26].

The crude fat content was within the expected level in fermented cowpeas-peanut milk samples after the end of fermentation. The use of cowpeas in the ratios and addition of water might have affected the crude fat content of the milk blends. Consequently, during fermentation, some of the lipids might have been utilised by the starter culture to yield energy [10]. Also, Aduol et al. [27] reported a significant difference $(p<0.05)$ in the low crude fat content $(0.3-0.5 \%)$ in fermented cowpeas milk Yoba Fiti GR-1 culture. The fat content observed in the fermented cowpea-peanut milk is beneficial to human health since it is within the recommended dietary intake level range for fat by the U.S. Department of Health and Human Services and U.S. Department of Agriculture Report of 2015.

The fibre content in fermented cowpeas-peanut milk sample could be attributed to the high dietary fibre $(14.1 \pm 0.3 \%$ dry matter (DM) present in processed cowpea of which $1.0 \pm 0.0 \% \mathrm{DM}$ is soluble fibre and $13 \pm 0.2 \% \mathrm{DM}$ is insoluble fibre) [28]. Also, the inclusion of peanut milk in the milk blend might have resulted in the observed fibre content.

The control (fermented cow milk) had a higher content of RS ( $8.40 \mathrm{~g} / 100 \mathrm{~g})$ than the fermented cowpea-peanut milk. This could be attributed to the breakdown of lactose into simple sugars by lactase produced by the bacteria [29]. The observed RS in the fermented cowpea-peanut milk could be explained by the action of Lacticaseibacillus rhamnosus Yoba as it produces $\alpha$-amylase and maltase which degrade the starch into malto-dextrins and simple sugars, respectively [30].

The moisture content of the fermented cowpea-peanut milk ranged between 89.8 and $91.5 \%$ and was higher than the fermented cow milk (83.6\%) because of the addition of water during the preparation of the plant milk samples.

The fermented cowpea-peanut milk samples had a higher ash content (1.04-1.26\%) than the control $(0.73 \%)$. There was a significant difference $(p<0.05)$ in the total ash content of the fermented cowpea-peanut milk and control samples. As the cowpea milk increased in the peanut: cowpea ratio, the ash content increased in the fermented cowpea-peanut milk because cowpea has an ash content range of $0.21-1.09 \%$ [31]. Furthermore, the increase in ash content can be explained by the breakdown of dry matter during fermentation as the probiotic culture degraded carbohydrates and proteins [32].

3.2. $p H$ and Total Acidity. The titratable acidity (TA) of the fermented cowpea-peanut milk samples was low (range $0.70-0.74 \% \mathrm{v} / \mathrm{v}$ lactic acid) as compared with that of the control $(0.84 \% \mathrm{v} / \mathrm{v})$ (Figure 2$)$. This study noted a decrease in the final $\mathrm{pH}$ and an increase in the TA of the cowpea-peanut 
TABle 1: Proximate composition of fermented cowpea-peanut milk with L. rhamnosus Yoba.

\begin{tabular}{lccccccc}
\hline \multirow{2}{*}{ Sample } & \multicolumn{5}{c}{ Mineral content $(\mathrm{g} / 100 \mathrm{~g})$} \\
& Crude protein & Crude fibre & Ash & Moisture & Carbohydrates & Crude fat & Reducing sugars \\
\hline $\mathrm{CM}:$ PM $(1: 1)$ & $6.3 \pm 0.01^{\mathrm{c}}$ & $1.18 \pm 0.01^{\mathrm{b}}$ & $1.26 \pm 0.03^{\mathrm{c}}$ & $89.8 \pm 0.01^{\mathrm{a}}$ & $5.18 \pm 1.80^{\mathrm{b}}$ & $3.40 \pm 0.01^{\mathrm{b}}$ & $2.10 \pm 0.01^{\mathrm{b}}$ \\
$\mathrm{CM}: \mathrm{PM}(2: 1)$ & $5.6 \pm 0.02^{\mathrm{b}}$ & $0.80 \pm 0.01^{\mathrm{a}}$ & $1.04 \pm 0.01^{\mathrm{b}}$ & $90.1 \pm 0.02^{\mathrm{b}}$ & $5.46 \pm 1.18^{\mathrm{b}}$ & $3.30 \pm 0.03^{\mathrm{b}}$ & $1.80 \pm 0.02^{\mathrm{a}}$ \\
$\mathrm{CM}:$ PM $(3: 1)$ & $6.8 \pm 0.02^{\mathrm{c}}$ & $0.72 \pm 0.03^{\mathrm{a}}$ & $1.10 \pm 0.05^{\mathrm{b}}$ & $91.5 \pm 0.03^{\mathrm{b}}$ & $6.05 \pm 1.03^{\mathrm{c}}$ & $3.55 \pm 0.01^{\mathrm{b}}$ & $2.20 \pm 0.05^{\mathrm{b}}$ \\
Control & $4.1 \pm 0.05^{\mathrm{a}}$ & $\mathrm{ND}$ & $0.73 \pm 0.07^{\mathrm{a}}$ & $83.6 \pm 0.01^{\mathrm{a}}$ & $4.25 \pm 0.06^{\mathrm{a}}$ & $3.04 \pm 0.04^{\mathrm{a}}$ & $8.40 \pm 0.06^{\mathrm{c}}$ \\
$P$ value & $<0.05$ & $<0.05$ & $<0.05$ & $<0.05$ & $<0.05$ & $<0.05$ & $<0.05$ \\
\hline
\end{tabular}

CM, cowpea milk; PM, peanut milk; ND, not determined; control, fermented cow milk. Values indicate the means of three replications \pm standard deviation. Means values within the same column with different superscript letters $\left({ }^{\mathrm{a}, \mathrm{b}, \mathrm{c}}\right)$ are significantly different $(p<0.05)$.

milk samples as the fermentation progressed. This could be ascribed to be the action of Lacticaseibacillus rhamnosus Yoba as it breaks down sugars into lactic acid [7]. A similar trend was also observed in the fermented cow milk (control). Mpofu et al. [33] observed similar trends. Adesokan et al. [34] reported the breakdown of sugars by LAB to produce lactic acid as well as other secondary fermentation products such as propionic, acetic, and butyric acids, hence the increase in TA. This is beneficial in limiting the growth of other harmful bacteria that may cause bad fermentations.

At the $6 \mathrm{~h}$ fermentation period, the cowpea-peanut milk had a low pH of 4.5 compared to 4.8 observed in the control sample (Figure 3). It can be explained that the $\mathrm{pH}$ of the cowpea-peanut milk samples after inoculation ( $\mathrm{pH}$ 6.3-6.4) was ideal to support the growth of Lacticaseibacillus rhamnosus Yoba in all samples at time $0 \mathrm{~h}$. Mäkinen et al. [35] found similar $\mathrm{pH}$ trends (6.7-4.34) for cow's milk fermented with related LAB cultures. This is evident by the increase in cell numbers of Lacticaseibacillus rhamnosus Yoba in all inoculated samples from time $0 \mathrm{~h}$ to $6 \mathrm{~h}$ during fermentation as shown in Figure 4. Liew et al. [36] reported the optimum $\mathrm{pH}$ range for growth of Lacticaseibacillus rhamnosus as 6.4-6.9. As the $\mathrm{pH}$ decreased during fermentation, it allowed for the survival of the Lacticaseibacillus rhamnosus Yoba in the cowpea-peanut milk but limited its rate of growth.

\subsection{DPPH Free Radical Scavenging and Total Antioxidant} Activity. The DPPH radical scavenging rate of the fermented cowpea-peanut milk samples ranged from 56 to $59 \%$ and was low in the control sample (41.6\%) at the end of the fermentation period (Figure 5). The ABTS + free radical scavenging rate (Figure 6) had similar trends as the DPPH radical scavenging rate. This could be attributed to the presence of phenolic acids, flavonoids, anthocyanins, and proanthocyanidins in cowpea [37]. The low antioxidant rate of the fermented cow's milk could be explained by the mode of action of the culture strain during the fermentation of milk [38]. This was in agreement with Lim et al. [39]. More so, the proteolysis of milk proteins such as $\alpha$-casein, $\alpha$-lactalbumin, and $\beta$-lactoglobulin by the action of starter culture and the production of bioactive peptides has been found to induce in vitro antioxidant capacity [40]. Also, the formation of conjugated linoleic acid (CLA) in fermented milk and the presence of coenzyme Q10 and vitamins A and E contribute to the antioxidant activity [41].
3.4. Amino Acids Composition. The amino acid composition of the fermented cowpea-peanut milk and control (cow milk) is given in Table 2. The fermented cowpeapeanut milk sample $(3: 1)$ with Lacticaseibacillus rhamnosus Yoba had the highest lysine content $(7.31 \mathrm{mg} / 100 \mathrm{~g})$ and was significantly different to all other fermented milk samples. This could be ascribed to the high concentration of cowpea used in the formutation and the high lysine content in cowpea [42]. The fermented cow milk samples had a methionine content $(1.95 \mathrm{mg} / 100 \mathrm{~g})$ that was not significantly different in fermented cowpea-peanut milk $(3: 1)$ and higher when compared to fermented cowpeapeanut milk samples $(1: 1$ and $2: 1)$ because cowpea has low methionine and cysteine content when compared to animal proteins [42]. During fermentation, Lacticaseibacillus rhamnosus Yoba was able to break down the proteins into peptides and free amino acids in all the fermented milk samples. Ghosh et al. [43] observed the presence of free histidine, cystine, histidine, and asparagine in fermented cow and soybean milk curd.

3.5. Mineral and Antinutritional Composition. Table 3 provides that fermented cow milk (control) had higher phosphorus, calcium, zinc, and sodium content because raw milk from cows is naturally an excellent source of many minerals. The process of filtering and wash water treatment using cheesecloth might have affected the mineral content of the fermented cowpea-peanut milk blends [10]. Difo et al. [44] observed a decrease of over $90 \%$ and $50 \%$ in calcium and iron after fermentation of cowpea flours, and this suggests the observed results. The blending of cowpeas and peanuts milk might have had an additive effect on some of the minerals, particularly iron and phosphorus. Cowpea is rich in potassium (957-1251 mg/100 g) with good amount of calcium (29-44 mg/100 g), magnesium (116-130 mg/100 g), and phosphorus (105-276 mg/100 g) [45].

The trypsin inhibitor and phytic acid content in fermented cowpea-peanut milk were very low after fermentation (Table 3). This could be due to the beneficial action of the probiotic microorganism in removing the antinutritive compounds that promote protein crosslinking (phenolic and tannin compounds) and inhibit digestive enzymes (trypsin and chymotrypsin inhibitors) from food material and production of microbial proteases, which could degrade and release some of the proteins from 


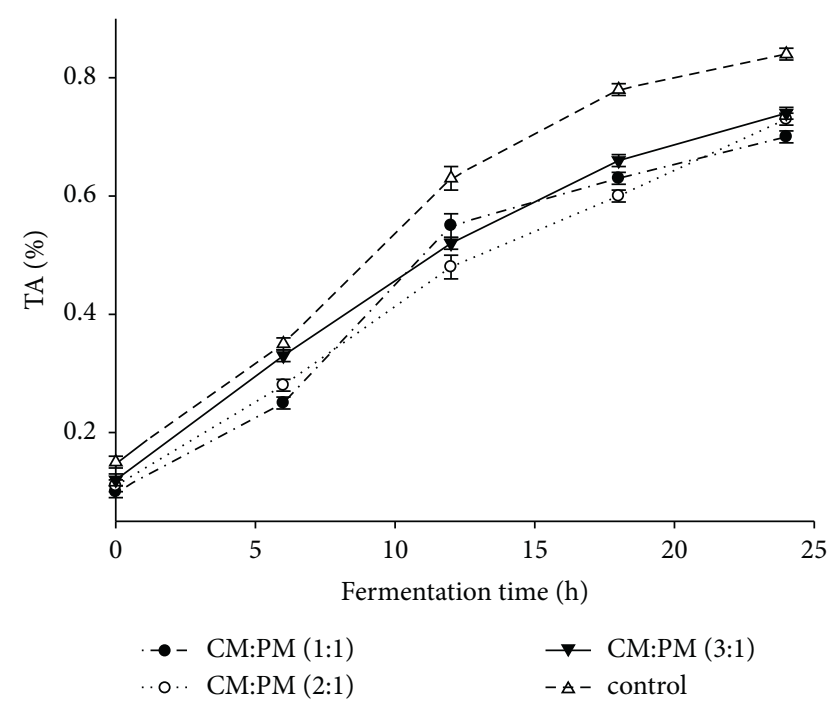

Figure 2: Titratable acidity values of four samples at different fermentation times. All the values are expressed as mean \pm SD $(n=3)$. CM, cowpea milk; PM, peanut milk.

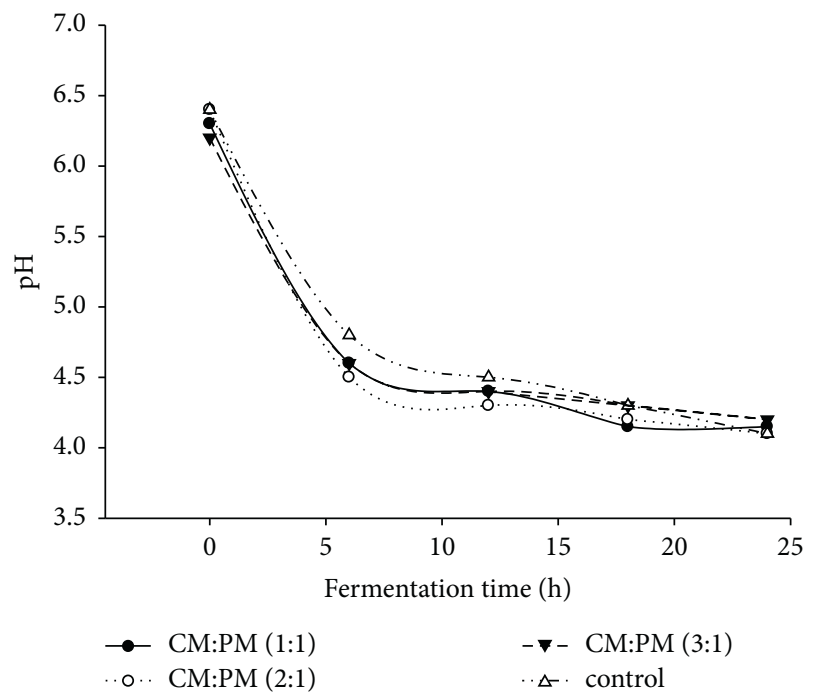

Figure 3: The $\mathrm{pH}$ values of four samples at different fermentation times. All the values are expressed as mean $\pm \mathrm{SD}(n=3)$. CM, cowpea milk; PM, peanut milk.

the matrix during fermentation $[7,46]$. Also, the use of $\mathrm{NaHCO}_{3}$ during soaking might have reduced the trypsin inhibitor and phytic acid content. Vadivel and Pugalenthi [47] reported a significant reduction in phytic acid (75-78\%), trypsin inhibitor activity (81-82\%), $\alpha$-amylase inhibitor activity $(82-84 \%)$, total free phenolics $(82-83 \%)$, and tannins (74-84\%) in velvet beans soaked in $\mathrm{NaHCO}_{3}$.

3.6. Cell Viability. The viable plate count of Lacticaseibacillus rhamnosus Yoba increased from 6.1-6.2 $\log \mathrm{CFU} / \mathrm{mL}$ to $7.7-8.1 \log \mathrm{CFU} / \mathrm{mL}(t=0 \mathrm{hr}$ ) after fermentation (Figure 4). This suggests that the cowpea-peanut milk matrix was an ideal environment to support the growth of Lacticaseibacillus rhamnosus Yoba. Cowpea is rich in

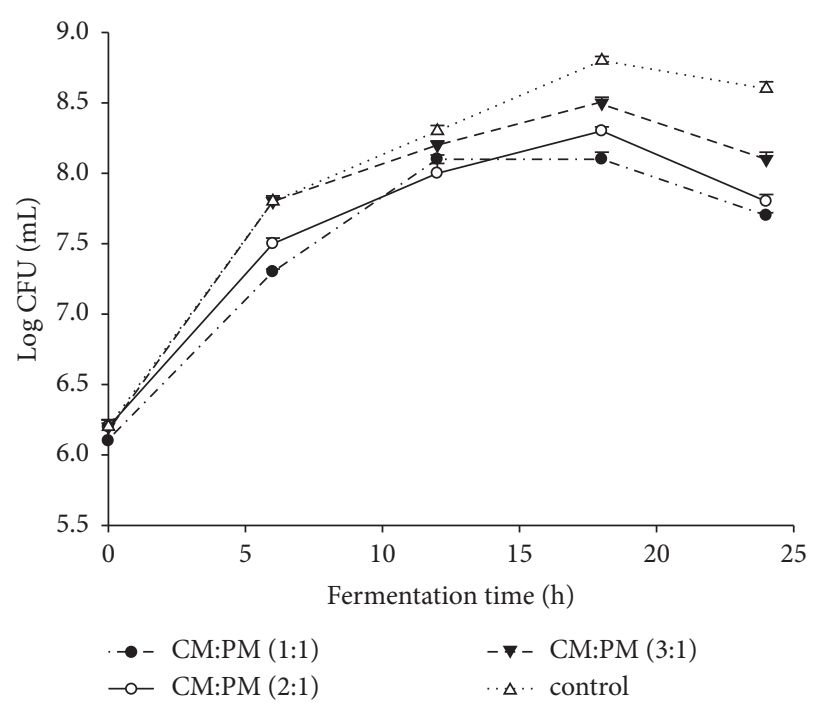

FIgURE 4: Lacticaseibacillus rhamnosus Yoba viable cell counts of four samples at different fermentation times. All the values are expressed as mean \pm SD $(n=3)$. CM, cowpea milk; PM, peanut milk.

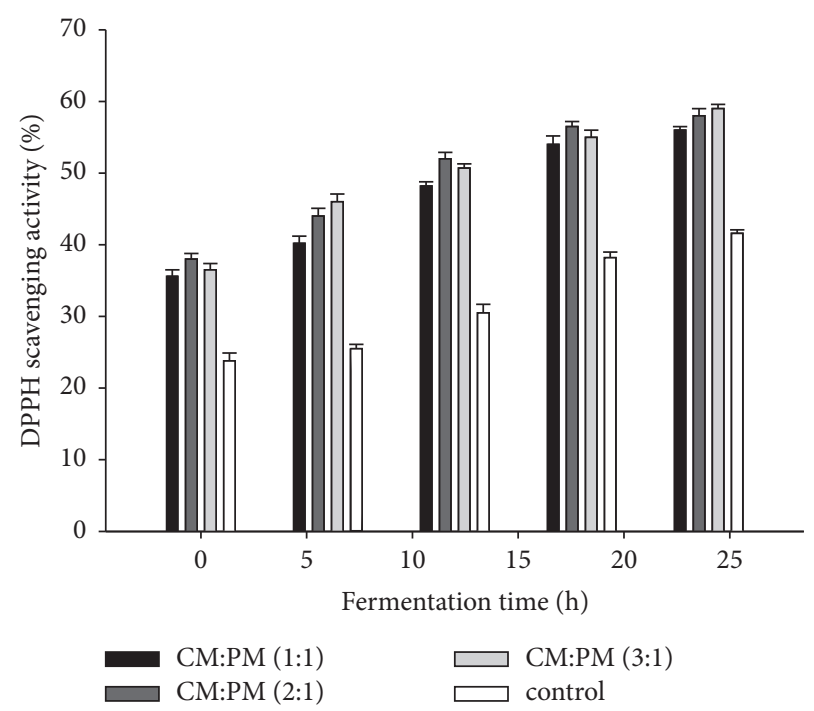

FIgURE 5: DPPH free radical scavenging rate of four samples at different fermentation times. All the values are expressed as mean \pm SD $(n=3)$. CM, cowpea milk; PM, peanut milk.

$\alpha$-galactosides (raffinose, verbascose, and stachyose), also referred to as the raffinose family oligosaccharides (RFOs) which act as prebiotics [48]. The prebiotics might have supported the growth of Lacticaseibacillus rhamnosus Yoba in fermented cowpea-peanut milk to some extent although the use of $\mathrm{NaHCO}_{3}$ during soaking might have lowered the oligosaccharides. This was supported by Vadivel and Pugalenthi [47]. The results of this study showed the potential to attain cell viability of over $6 \log \mathrm{CFU} / \mathrm{mL}$ in fermented cowpea-peanut milk that is comparable to fermented cow's milk (control). This is similar to results obtained on the survival of Lacticaseibacillus rhamnosus GG in various leguminous porridges [49]. 


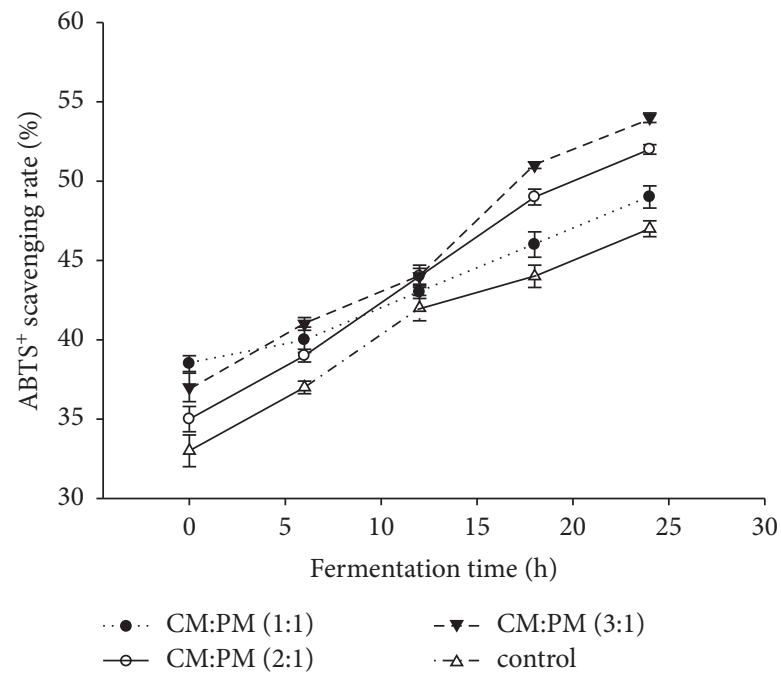

FiguRE 6: ABTS + free radical scavenging rate of four samples at different fermentation times. All the values are expressed as mean \pm SD $(n=3)$. CM, cowpea milk; PM, peanut milk.

TABLe 2: Amino acid content of fermented cowpea-peanut milk with L. rhamnosus Yoba.

\begin{tabular}{|c|c|c|c|c|c|}
\hline \multirow{2}{*}{ Amino acid (g/100 g) } & \multicolumn{4}{|c|}{ Fermented milk samples } & \multirow{2}{*}{$P$ value } \\
\hline & $\mathrm{CM}: \mathrm{PM}(1: 1)$ & $\mathrm{CM}: \mathrm{PM}(2: 1)$ & $\mathrm{CM}: \mathrm{PM}(3: 1)$ & Control & \\
\hline \multicolumn{6}{|l|}{ Essential } \\
\hline Valine & $4.40 \pm 0.01^{\mathrm{a}}$ & $4.86 \pm 0.02^{\mathrm{a}}$ & $5.01 \pm 0.01^{\mathrm{b}}$ & $4.78 \pm 0.05^{\mathrm{a}}$ & $<0.05$ \\
\hline Lysine & $6.30 \pm 0.02^{\mathrm{a}}$ & $7.31 \pm 0.02^{\mathrm{b}}$ & $6.70 \pm 0.01^{\mathrm{a}}$ & $6.60 \pm 0.06^{\mathrm{a}}$ & $<0.05$ \\
\hline Threonine & $3.26 \pm 0.01^{\mathrm{b}}$ & $2.65 \pm 0.05^{\mathrm{a}}$ & $3.80 \pm 0.01^{\mathrm{c}}$ & $3.85 \pm 0.04^{c}$ & $<0.05$ \\
\hline Tryptophan & $1.50 \pm 0.03^{\mathrm{a}}$ & $2.10 \pm 0.06^{\mathrm{b}}$ & $2.65 \pm 0.07^{\mathrm{c}}$ & $1.15 \pm 0.05^{\mathrm{a}}$ & $<0.05$ \\
\hline Leucine & $6.60 \pm 0.01^{\mathrm{a}}$ & $8.02 \pm 0.01^{\mathrm{c}}$ & $8.75 \pm 0.05^{\mathrm{c}}$ & $7.08 \pm 0.05^{\mathrm{b}}$ & $<0.05$ \\
\hline Phenylalanine & $5.23 \pm 0.01^{\mathrm{b}}$ & $5.80 \pm 0.03^{\mathrm{b}}$ & $5.65 \pm 0.07^{\mathrm{b}}$ & $4.10 \pm 0.02^{\mathrm{a}}$ & $<0.05$ \\
\hline Isoleucine & $3.05 \pm 0.05^{\mathrm{a}}$ & $2.96 \pm 0.06^{\mathrm{a}}$ & $3.40 \pm 0.01^{\mathrm{b}}$ & $4.25 \pm 0.08^{\mathrm{c}}$ & $<0.05$ \\
\hline Tyrosine & $1.08 \pm 0.02^{\mathrm{a}}$ & $1.23 \pm 0.08^{\mathrm{a}}$ & $1.80 \pm 0.04^{\mathrm{b}}$ & $4.60 \pm 0.06^{\mathrm{c}}$ & $<0.05$ \\
\hline \multicolumn{6}{|l|}{ Nonessential } \\
\hline Serine & $2.15 \pm 0.02^{\mathrm{a}}$ & $1.90 \pm 0.07^{\mathrm{a}}$ & $2.25 \pm 0.08^{\mathrm{b}}$ & $4.74 \pm 0.04^{\mathrm{c}}$ & $<0.05$ \\
\hline Proline & $2.60 \pm 0.06^{\mathrm{a}}$ & $2.78 \pm 0.05^{\mathrm{b}}$ & $2.46 \pm 0.07^{\mathrm{a}}$ & $6.85 \pm 0.09^{c}$ & $<0.05$ \\
\hline Glycine & $2.22 \pm 0.06^{\mathrm{b}}$ & $2.70 \pm 0.05^{\mathrm{c}}$ & $2.90 \pm 0.07^{c}$ & $1.05 \pm 0.05^{\mathrm{a}}$ & $<0.05$ \\
\hline Alanine & $3.08 \pm 0.04^{\mathrm{b}}$ & $3.65 \pm 0.08^{\mathrm{b}}$ & $4.10 \pm 0.01^{\mathrm{c}}$ & $2.30 \pm 0.02^{\mathrm{a}}$ & $<0.05$ \\
\hline Glutamic & $16.6 \pm 0.05^{\mathrm{c}}$ & $15.4 \pm 0.06^{\mathrm{b}}$ & $17.3 \pm 0.07^{\mathrm{c}}$ & $12.4 \pm 0.06^{\mathrm{a}}$ & $<0.05$ \\
\hline Methionine & $1.70 \pm 0.06^{\mathrm{a}}$ & $1.50 \pm 0.05^{\mathrm{a}}$ & $1.86 \pm 0.08^{\mathrm{b}}$ & $1.95 \pm 0.07^{\mathrm{b}}$ & $<0.05$ \\
\hline Histidine & $2.01 \pm 0.08^{\mathrm{b}}$ & $1.87 \pm 0.02^{\mathrm{a}}$ & $1.90 \pm 0.03^{\mathrm{a}}$ & $1.88 \pm 0.08^{\mathrm{a}}$ & $<0.05$ \\
\hline
\end{tabular}

$\mathrm{CM}$, cowpea milk; PM, peanut milk; control, fermented cow milk. Values indicate the means of three replications \pm standard deviation. Means values within the same row with different superscript letters $\left({ }^{\mathrm{a},}, \mathrm{b}, \mathrm{c}\right)$ are significantly different $(p<0.05)$.

TAble 3: Mineral and antinutritional composition of fermented cowpea-peanut milk with L. rhamnosus Yoba.

\begin{tabular}{|c|c|c|c|c|c|c|c|c|c|}
\hline \multirow{2}{*}{ Sample } & \multicolumn{7}{|c|}{ Mineral content $(\mathrm{mg} / 100 \mathrm{~g})$} & \multirow{2}{*}{$\begin{array}{c}\text { Phytic acid } \\
(\%)\end{array}$} & \multirow{2}{*}{$\begin{array}{c}\text { Trypsin } \\
\text { inhibitor (TIU/ } \\
\mathrm{mg})\end{array}$} \\
\hline & Phosphorus & Calcium & Iron & Magnesium & Zinc & Sodium & Potassium & & \\
\hline $\begin{array}{l}\text { CM : PM } \\
(1: 1)\end{array}$ & $60.2 \pm 0.06^{\mathrm{a}}$ & $45.3 \pm 0.08^{\mathrm{a}}$ & $0.48 \pm 0.05^{\mathrm{b}}$ & $20.8 \pm 0.06^{\mathrm{b}}$ & $0.18 \pm 0.06^{\mathrm{a}}$ & $13.8 \pm 0.08^{\mathrm{a}}$ & $222.5 \pm 0.05^{\mathrm{c}}$ & $0.34 \pm 0.02^{\mathrm{a}}$ & $1.05 \pm 0.03^{\mathrm{b}}$ \\
\hline $\begin{array}{l}\mathrm{CM}: \mathrm{PM} \\
(2: 1)\end{array}$ & $66.7 \pm 0.07 b$ & $51.2 \pm 0.02^{\mathrm{b}}$ & $0.50 \pm 0.06^{\mathrm{b}}$ & $18.6 \pm 0.02^{\mathrm{b}}$ & $0.21 \pm 0.05^{\mathrm{a}}$ & $13.4 \pm 0.05^{\mathrm{a}}$ & $202.3 \pm 0.01^{b}$ & $0.30 \pm 0.05^{\mathrm{a}}$ & $1.12 \pm 0.04^{\mathrm{b}}$ \\
\hline $\begin{array}{l}\text { CM : PM } \\
(3: 1)\end{array}$ & $69.2 \pm 0.04^{\mathrm{b}}$ & $60.4 \pm 0.07^{\mathrm{b}}$ & $0.58 \pm 0.03^{\mathrm{b}}$ & $21.4 \pm 0.05^{\mathrm{c}}$ & $0.27 \pm 0.06^{\mathrm{a}}$ & $14.2 \pm 0.03^{\mathrm{a}}$ & $243.1 \pm 0.06^{\mathrm{c}}$ & $0.32 \pm 0.06^{\mathrm{a}}$ & $0.86 \pm 0.08^{\mathrm{a}}$ \\
\hline Control & $123.2 \pm 0.05^{\mathrm{c}}$ & $145.5 \pm 0.06^{\mathrm{c}}$ & $0.06 \pm 0.05^{\mathrm{a}}$ & $8.1 \pm 0.04^{\mathrm{a}}$ & $0.48 \pm 0.02^{\mathrm{b}}$ & $48.4 \pm 0.06^{\mathrm{a}}$ & $115.7 \pm 0.05^{\mathrm{a}}$ & ND & ND \\
\hline$P$ value & $<0.05$ & $<0.05$ & $<0.05$ & $<0.05$ & $<0.05$ & $<0.05$ & $<0.05$ & $<0.05$ & $<0.05$ \\
\hline
\end{tabular}

CM, cowpea milk; PM, peanut milk; ND, not determined; control, fermented cow milk. Values indicate the means of three replications \pm standard deviation. Means values within the same column with different superscript letters $\left({ }^{a}, b, c\right)$ are significantly different $(p<0.05)$. 
TABLE 4: Mean sensory scores of fermented cowpea-peanut milk with Lacticaseibacillus rhamnosus Yoba.

\begin{tabular}{lcccccc}
\hline Sample & Taste & Colour & Texture & Aroma & Appearance & Overall acceptability \\
\hline AAB & $3.9 \pm 0.1^{\mathrm{a}}$ & $3.7 \pm 0.1^{\mathrm{a}}$ & $3.9 \pm 0.2^{\mathrm{b}}$ & $4.0 \pm 0.1^{\mathrm{a}}$ & $3.8 \pm 0.1^{\mathrm{b}}$ & $4.0 \pm 0.1^{\mathrm{a}}$ \\
$\mathrm{ABA}$ & $4.0 \pm 0.1^{\mathrm{a}}$ & $3.5 \pm 0.2^{\mathrm{a}}$ & $3.7 \pm 0.1^{\mathrm{a}}$ & $3.9 \pm 0.1^{\mathrm{a}}$ & $3.7 \pm 0.1^{\mathrm{s}}$ & $3.9 \pm 0.1^{\mathrm{a}}$ \\
$\mathrm{ABB}$ & $3.8 \pm 0.2^{\mathrm{a}}$ & $3.6 \pm 0.1^{\mathrm{a}}$ & $3.5 \pm 0.1^{\mathrm{a}}$ & $3.8 \pm 0.2^{\mathrm{a}}$ & $3.6 \pm 0.1^{\mathrm{s}}$ & $3.8 \pm 0.2^{\mathrm{a}}$ \\
$\mathrm{BAA}$ & $4.0 \pm 0.1^{\mathrm{a}}$ & $4.0 \pm 0.1^{\mathrm{b}}$ & $4.0 \pm 0.2^{\mathrm{c}}$ & $4.0 \pm 0.1^{\mathrm{a}}$ & $4.1 \pm 0.1^{\mathrm{c}}$ & $4.1 \pm 0.0^{\mathrm{a}}$ \\
$P$ value $^{\mathrm{a}}$ & $\mathrm{ns}$ & $<0.05$ & $<0.05$ & ns & $<0.05$ & $n s$ \\
\hline
\end{tabular}

$\mathrm{AAB}, \mathrm{CM}: \mathrm{PM}(1: 1)+$ sugar + vanilla; ABA, CM: PM (2:1) + sugar + vanilla; ABB, CM:PM (3:1) + sugar + vanilla; BAA, control + sugar + vanilla; ns = not significant. Mean \pm standard deviations are reported. ${ }^{\mathrm{a}}$ Friedman's test. Means values within the same column with different superscript letters $\left({ }^{\mathrm{a}}\right.$, b, $\left.\mathrm{c}\right)$ are significantly different $(p<0.05)$.

3.7. Sensory Evaluation. The mean scores for the sensory attributes of the fermented cowpea-milks and control samples are given in Table 4 . The observed results indicated a significant difference $(p<0.05)$ in colour, texture, and appearance. However, no significant differences $(p>0.05)$ were observed in taste, aroma, and overall acceptability. The ratings of colour in fermented cow's milk could be attributed to the reflection of fat in cow's milk. The taste might have been influenced by the low residual sugar content and titratable acidity although the addition of sugar greatly improved the rating for taste. The flavour ratings could be attributed to the presence of acetaldehyde, (E)-2-pentenal, hexanal, 3-methyl-butanal, 2, 3-butanedione, (E)-2-octenal, nonanal, acetoin, 2-non-anone, ethenyl ester formic acid, and 2-heptanone [50], especially in fermented cow's milk. Also, the microbial catabolism of lactose, proteins, and fatty acids by Lacticaseibacillus rhamnosus Yoba could have produced acetaldehyde, acetoin, and diacetyl [51]. Fermented milk produces small amounts $(0.001-1,000 \mu \mathrm{g} / \mathrm{L})$ of volatiles that influence the aroma and flavour thresholds [52]. They were no significant differences in the overall acceptability of the fermented cowpea-peanut milk and cow milk.

\section{Conclusion}

The application of Lacticaseibacillus rhamnosus Yoba as a method of fermenting cowpea-peanut milk proved an effective food processing technique for enhancing customer acceptability and improving the nutritional content. The cowpea-peanut milk matrices were able to support the growth of Lacticaseibacillus rhamnosus Yoba, and this was shown by the viable cell counts of 7.7-8.1 log CFU/mL after fermentation. The TA had a significant effect on the amount of $\mathrm{pH}$ obtained. The decrease in $\mathrm{pH}$ from 6.3 to 4.3 resulted in the significant growth of Lacticaseibacillus rhamnosus Yoba during fermentation. However, $\mathrm{pH} 4.1$ decreased the growth of the probiotic bacteria although it allowed for its survival. There was an increase in antioxidant activity and reduction in antinutritive compounds as the Lacticaseibacillus rhamnosus Yoba degrade the proteins to produce peptides. The increase in iron and potassium content may be attributed to the possible breakdown of the phytates during fermentation and the release of bound minerals. The results confirm the potential economic benefits of using the underutilised legume crops in the development of novel fermented cowpea-peanut milk with a generic probiotic.
This technique is beneficial in the removal of antinutrients and improving customer acceptability of fermented legumebased milk. Further studies will focus on the bioaccessibility and bioavailability of minerals in the fermented cowpeapeanut milk using the generic probiotic. The possibility of inactivation of pathogenic microorganisms in the media of cowpea-peanut milk fermented with Lacticaseibacillus rhamnosus Yoba will also be explored in our further studies.

\section{Data Availability}

The data used to support the findings of this study are available from the corresponding author upon request.

\section{Conflicts of Interest}

The authors declare that there are no conflicts of interest.

\section{Acknowledgments}

The authors would like to thank the Standards Association of Zimbabwe (SAZ) for their expert advice in analysis and all volunteer participants in sensory evaluation.

\section{References}

[1] G. Sebastiani, A. Herranz Barbero, C. Borrás-Novell et al., "The effects of vegetarian and vegan diet during pregnancy on the health of mothers and offspring," Nutrients, vol. 11, no. 3, p. $557,2019$.

[2] E. F. Aydar, S. Tutuncu, and B. Ozcelik, "Plant-based milk substitutes: bioactive compounds, conventional and novel processes, bioavailability studies, and health effects," Journal of Functional Foods, vol. 70, Article ID 103975, 2020.

[3] P. E. S. Munekata, R. Domínguez, S. Budaraju et al., "Effect of innovative food processing technologies on the physicochemical and nutritional properties and quality of non-dairy plant-based beverages," Foods, vol. 9, no. 3, p. 288, 2020.

[4] SADC, "Regional food security update: SADC food security quarterly update-2019/2020 Agricultural Season," 2020, http://www.sadc.int/fanr.

[5] FAO/WHO, Guidelines for the Evaluation of Probiotics in Food. Report of a Joint FAO/WHO Working Group on Drafting Guidelines for the Evaluation of Probiotics in Food, FAO, Ontario, Canada, 2002.

[6] R. Kort and W. Sybesma, "Probiotics for every body," Trends in Biotechnology, vol. 30, no. 12, pp. 613-615, 2012.

[7] A. Chawafambira, M. M. Sedibe, A. Mpofu, and M. Achilonu, "Probiotic potential, iron and zinc bioaccessibility, and sensory quality of Uapaca kirkiana fruit jam fermented with 
Lactobacillus rhamnosus yoba," International Journal of Food Science, vol. 2020, Article ID 8831694, 11 pages, 2020.

[8] J. Zheng, S. Wittouck, E. Salvetti et al., "A taxonomic note on the genus Lactobacillus: description of 23 novel genera, emended description of the genus Lactobacillus Beijerinck 1901, and union of Lactobacillaceae and Leuconostocaceae," International Journal of Systematic and Evolutionary Microbiology, vol. 70, no. 4, pp. 2782-2858, 2020.

[9] R. P. Deshpande, M. S. Chinnan, and R. D. Phillips, "Process development of a chocolate-flavoured peanut-soy beverage," International Journal of Food Science and Technology, vol. 43, no. 5, pp. 886-894, 2008.

[10] H. Aidoo, E. Sakyi-Dawson, K. Tano-Debrah, and F. K. Saalia, "Development and characterization of dehydrated peanut-cowpea milk powder for use as a dairy milk substitute in chocolate manufacture," Food Research International, vol. 43, pp. 79-85, 2010.

[11] I. O. Akinyele and I. A. Abudu, "Acceptability and nutrient content of milk substitutes from four cultivars of cowpeas (Vigna unguiculata)," Journal of Food Science, vol. 55, no. 3, pp. 701-702, 1990.

[12] K. Asiamah, Process Optimization of Cowpea-Peanut Milk, M.Phil. Thesis, Department of Nutrition and Food Science, University of Ghana, Accra, Ghana, 2005.

[13] S. Sethi, S. K. Tyagi, and R. K. Anurag, "Plant-based milk alternatives an emerging segment of functional beverages: a review," Journal of Food Science and Technology, vol. 53, pp. 3408-3423, 2016.

[14] M. E. Zujko and A. M. Witkowska, "Antioxidant potential and polyphenol content of beverages, chocolates, nuts, and seeds," International Journal of Food Properties, vol. 17, no. 1, pp. 86-92, 2014.

[15] X. Zhang, S. Zhang, B. Xie, and Z. Sun, "Influence of lactic acid bacteria fermentation on physicochemical properties and antioxidant activity of chickpea yam milk," Journal of Food Quality, vol. 2021, Article ID 5523356, 2021.

[16] A. I. Sanni, A. A. Onilude, and E. O. Adeleke, "Preparation and characteristics of lactic acid fermented cowpea milk," Zeitschrift für Lebensmitteluntersuchung und -Forschung A, vol. 208, no. 3, pp. 225-229, 1999.

[17] V. U. Rani and B. V. Pradeep, "Antioxidant properties of soy milk fermented with Lactobacillus paracasei KUMB B005," International Journal of Pharmaceutical Sciences Review and Research, vol. 30, pp. 39-42, 2015.

[18] AOAC, Official Methods of Analysis of the Association of Official Analytical Chemists, AOAC International, Gaithersburg, MD, USA, 18th edition, 2005.

[19] S. S. Nielsen, "Phenol-sulfuric acid method for total carbohydrates," in Food Analysis Laboratory Manual: Food Science Texts Series, pp. 47-53, Springer, Boston, MA, USA, 2010.

[20] M. L. Kakade, N. Simons, and I. E. Liener, "Evaluation of natural vs. synthetic substrates for measuring the antitryptic activity of soybean samples," Cereal Chemistry, vol. 46, pp. 518-526, 1969.

[21] V. A. McKie and B. V. MccleAry, "A novel and rapid colorimetric method for measuring total phosphorus and phytic acid in foods and animal feeds," Journal of AOAC International, vol. 99, no. 3, pp. 738-743, 2016.

[22] A. Chawafambira, Q. Nyoni, and T. Mkungunugwa, "The potential of utilizing Provitamin A-biofortified maize in producing Mutwiwa, a Zimbabwean traditional fermented food," Food Sciences and Nutrition, vol. 9, no. 3, pp. 1521-1529, 2021.
[23] X. Yu, M. Zhao, F. Liu, S. Zeng, and J. Hu, "Antioxidants in volatile Maillard reaction products: identification and interaction," Lebensmittel-Wissenschaft und -Technologie- Food Science and Technology, vol. 53, no. 1, pp. 22-28, 2013.

[24] S. S. Arya, A. R. Salve, and S. Chauhan, "Peanuts as functional food: a review," Journal of Food Science \& Technology, vol. 53, no. 1, pp. 31-41, 2016.

[25] A. O. Ashogbon and E. T. Akintayo, "Isolation and characterization of starches from two cowpea (Vigna unguiculata) cultivars," The International Food Research Journal, vol. 20, p. 3093, 2013.

[26] K. Foster-Powell, S. H. Holt, and J. C. Brand-Miller, "International table of glycemic index and glycemic load values: 2002," The American Journal of Clinical Nutrition, vol. 76, no. 1, pp. 5-56, 2002.

[27] K. O. Aduol, A. N. Onyango, and S. M. Imathiu, "Proximate, microbial and sensory characteristics of cowpea milk fermented with probiotic starter cultures," European Journal of Agriculture and Food Sciences, vol. 22, no. 4, p. 2, 2020.

[28] Y. N. Sreerama, V. B. Sashikala, V. M. Pratape, and V. Singh, "Nutrients and antinutrients in cowpea and horse gram flours in comparison to chickpea flour: evaluation of their flour functionality," Food Chemistry, vol. 131, no. 2, pp. 462-468, 2012.

[29] D. M. Linares, C. Gómez, E. Renes et al., "Lactic acid bacteria and bifidobacteria with potential to design natural biofunctional health-promoting dairy foods," Frontiers in Microbiology, vol. 8, p. 846, 2017.

[30] S. G. Nkhata, E. Ayua, E. H. Kamau, and J.-B. Shingiro, "Fermentation and germination improve nutritional value of cereals and legumes through activation of endogenous enzymes," Food Sciences and Nutrition, vol. 6, no. 8, pp. 2446-2458, 2018.

[31] J. Awika, S. Talcott, B. B. Singh et al., "Increasing utilization of cowpeas to promote health and food security in Africa," Cereal Foods World, vol. 57, 2011.

[32] C. N. Day and R. O. Morawicki, "Effects of fermentation by yeast and amylolytic lactic acid bacteria on grain sorghum protein content and digestibility," Journal of Food Quality, vol. 2018, Article ID 3964392, 8 pages, 2016.

[33] A. Mpofu, A. R. Linnemann, W. Sybesma, R. Kort, M. J. R. Nout, and E. J. Smid, "Development of a locally sustainable functional food based on mutandabota, a traditional food in Southern Africa," Journal of Dairy Science, vol. 97, no. 5, pp. 2591-2599, 2014.

[34] I. A. Adesokan, B. B. Odetoyinbo, Y. A. Ekanola, R. E. Avanrenren, and S. Fakorede, "Production of Nigerian nono using lactic starter cultures," Pakistan Journal of $\mathrm{Nu}$ trition, vol. 10, no. 3, pp. 203-207, 2011.

[35] O. E. Mäkinen, V. Wanhalinna, E. Zannini, and E. K. Arendt, "Foods for special dietary needs: non-dairy plant-based milk substitutes and fermented dairy-type products," Critical Reviews in Food Science and Nutrition, vol. 56, no. 3, pp. 339349, 2016.

[36] S. L. Liew, A. B. Ariff, A. R. Raha, and Y. W. Ho, "Optimization of medium composition for the production of a probiotic microorganism, Lactobacillus rhamnosus, using response surface methodology," International Journal of Food Microbiology, vol. 102, no. 2, pp. 137-142, 2005.

[37] F. B. Apea-Bah, J. C. Serem, M. J. Bester, and K. G. Duodu, "Phenolic composition and antioxidant properties of koose, a deep-fat fried cowpea cake," Food Chemistry, vol. 237, pp. 247-256, 2017. 
[38] F. Melini, V. Melini, F. Luziatelli, A. G. Ficca, and M. Ruzzi, "Health-promoting components in fermented foods: an upto-date systematic review," Nutrients, vol. 11, no. 5, p. 1189, 2019.

[39] S.-M. Lim, "Microbiological, physicochemical, and antioxidant properties of plain yogurt and soy yogurt," Korean Journal of Microbiology, vol. 49, no. 4, pp. 403-414, 2013.

[40] A. Fardet and E. Rock, "In vitro and in vivo antioxidant potential of milks, yoghurts, fermented milks and cheeses: a narrative review of evidence," Nutrition Research Reviews, vol. 31, no. 1, pp. 52-70, 2018.

[41] C. Grażyna, C. Hanna, A. Adam, and B. M. Magdalena, "Natural antioxidants in milk and dairy products," International Journal of Dairy Technology, vol. 70, pp. 165-178, 2017.

[42] M. P. Timko and B. B. Singh, "Cowpea, a multifunctional legume," in Genomics of Tropical Crop Plants, P. H. Moore and R. Ming, Eds., pp. 227-258, Springer, New York, NY, USA, 2008.

[43] D. Ghosh, D. K. Chattoraj, and P. Chattopadhyay, "Studies on changes in microstructure and proteolysis in cow and soy milk curd during fermentation using lactic cultures for improving protein bioavailability," Journal of Food Science \& Technology, vol. 50, no. 5, pp. 979-985, 2013.

[44] H. V. Difo, E. Onyike, D. A. Ameh, U. S. Ndidi, and G. C. Njoku, "Chemical changes during open and controlled fermentation of cowpea (Vigna unguiculata) flour," International Journal of Food and Nutritional Sciences, vol. 5, pp. 1-10, 2014.

[45] A. C. da Silva, D. da Costa Santos, D. L. T. Junior, P. B. da Silva, R. C. dos Santos, and A. Siviero, "Cowpea: a strategic legume species for food security and health," in Legume Seed Nutraceutical Research, J. Jimenez-Lopez and A. Clemente, Eds., IntechOpen, London, UK, 2018.

[46] B. Çabuk, M. G. Nosworthy, A. K. Stone et al., "Effect of fermentation on the protein digestibility and levels of nonnutritive compounds of pea protein concentrate," Food Technology and Biotechnology, vol. 56, pp. 257-264, 2018.

[47] V. Vadivel and M. Pugalenthi, "Effect of soaking in sodium bicarbonate solution followed by autoclaving on the nutritional and antinutritional properties of velvet bean seeds," Journal of Food Processing and Preservation, vol. 33, no. 1, pp. 60-73, 2009.

[48] M. Petruláková and Ľ Valík, "Evaluation of legumes as a substrate for probiotic strain Lactobacillus rhamnosus GG," Acta Alimentaria, vol. 44, pp. 268-275, 2015.

[49] C. Martínez-Villaluenga, J. Frias, and C. Vidal-Valverde, "Alpha-galactosides: antinutritional factors or functional ingredients?" Critical Reviews in Food Science and Nutrition, vol. 48, pp. 301-316, 2008.

[50] T. Dan, W. Ren, Y. Liu et al., "Volatile flavor compounds profile and fermentation characteristics of milk fermented by Lactobacillus delbrueckii subsp. bulgaricus," Frontiers in Microbiology, vol. 10, p. 2183, 2019.

[51] H. Cheng, "Volatile flavor compounds in yogurt: a review," Critical Reviews in Food Science and Nutrition, vol. 50, no. 10, pp. 938-950, 2010.

[52] R. Imhof, H. Glättli, and J. O. Bosset, "Volatile organic aroma compounds produced by thermophilic and mesophilic mixed strain dairy starter cultures," LebensmittelWissenschaft und -Technologie- Food Science and Technology, vol. 27, no. 5, pp. 442-449, 1994. 